\title{
Management of Waste Treatment as an Alternative Energy Source and its Fiscal Support
}

\author{
Agunan, P. Samosir \\ Senior Researcher at Fiscal Policy Agency, Ministry of Finance Indonesia \\ agunans@gmail.com
}

\begin{abstract}
In recent years, the management of waste treatment in Indonesia has become a critical issue among the stakeholders both in the government and the private sector. One way to significantly reduce waste in each region is to use incinerator technology. This technology has developed in Japan, South Korea and Europe. The burning of waste can produce electricity or the so-called waste to energy. However, to build a power plant that utilizes waste requires policy support from the Central and Regional Governments. This study seeks to identify the types of support that Central and Regional Governments can provide to develop waste to energy.
\end{abstract}

Key words: Waste to energy, renewable energy, fiscal support, tipping fee, feed in tariff.

\section{Introduction}

To realize the national energy policy target until 2025, the Government has set a target of achieving an electrification ratio of close to 100 percent by 2020 and achieving an optimal energy mix through the use of new energy and renewable energy (EBT). The use of EBT is targeted at least 23 percent in 2025 and 31 percent in 2050. In December 2015 at COP 21 Paris, President Joko Widodo has made a commitment that Indonesia will reduce emissions by 29 percent without international support and by 41 percent with international support. However, the realized renewable energy use in 2015 is still far from the commitments. As seen in the following table, the highest installed capacity of a power plant is a hydro-sourced generator (10.1 percent of its potential), while geothermal and biomass around 5 percent of their potentials.

\section{Table 1: Potential and Capacity Installed - Renewable Energy}

\begin{tabular}{|c|c|c|c|c|c|}
\hline No & Type of Plant & $\begin{array}{l}\text { Potential } \\
\text { (MW) }\end{array}$ & $\begin{array}{l}\text { Installed } \\
\text { (MW) }\end{array}$ & Capacity & Ratio (\%) \\
\hline 1. & Hydro & 75,000 & 7,573 & & 10.1 \\
\hline 2. & Geothermal & 28,910 & 1,344 & & 4.65 \\
\hline 3. & Bioenergy & 32,654 & 1,717 & & 5.26 \\
\hline 4. & Solar & $4.80 \mathrm{kWh} / \mathrm{m}^{2} /$ day & 48 & & \\
\hline 5. & Wind & $3-6 \mathrm{~m} / \mathrm{s}$ & 1,87 & & \\
\hline 6. & Marine & 49,000 & - & & \\
\hline
\end{tabular}

Source: Ministry of Energy and Mineral Resource, 2015

In reaching the above targets, Indonesian government has to see many obstacles. The biggest challenge is the determination of tariffs, either purchasing electricity from PT PLN (feed in tariff) or the tariff charge to PT PLN customers. The government can not set high tariffs for renewable energy. The consequences of high feed in tariffs result in expensive tariffs being charged to electricity customers. The use of renewable energy will have positive impact on reducing emissions compared to the use of fossil energy. Yet, it is ironic since the use of renewable energy is expected -ceteris paribus- to reach a maximum of only 20 percent in 2025 . One alternative for renewable energy based power plants is waste to energy (WtE). The Indonesian government has issued several feed-in-tariff regulations that are quite competitive for investors to invest. However, the implementation is still facing problems because of the big difference between feed in tariffs and the basic cost of electricity supply generation by PLN. Such conditions above make the efforts to meet the government commitments to accelerate the use of renewable energy in the future difficult to realize. Another problem is the large difference in the price of purchasing electricity from waste and the selling price determined by the government results in subsidies. For example: the purchase price of PLN from WtE is IDR 2,533 per kWh (USD 18.77 cents / exchange rate IDR 13,500), while the PLN BPP in Java Bali is IDR 880 per kWh. Thus the subsidy incurred by the state budget is Rp1, 653 per $\mathrm{kWh}$. Another challenge for policy makers in ministries and institutions comes from the adopted thermal technology and the environmental stakeholders concern that the combustion process of waste can produce dioxin toxins - a very dangerous substance for health. Until 
now there is no appropriate technology in waste management for WtE in Indonesia (Ministry of Energy and Mineral Resources, 2015).

The other issue related to managing waste to become one of the electricity sources is the high investment costs for WtE development. The high investment costs results in expensive electricity prices from WtE to PT PLN. Land supply is the biggest challenge in WtE development investment. Often the delay in the construction of WtE is due to unavailability of land. The next issue is the tipping fee which is an additional burden for the Regional Government in the Regional Budget. Based on the explanation above, the objectives of this study are : (i) to explore the potential of WtE to be able to contribute as a new renewable energy source in the cities of Surabaya, West Java Province and Surakarta, (ii) to analyze the amount of tipping fees and electricity prices produced by the generator, as well as the parties involved in its determination, and (iii) to analyze the form of possible support by the Central Government to the regions that have the mandate to build a waste-based power plant. Management of Waste Treatment in Indonesia: Waste is one of the typical problems of urban and tourist areas, as a result of their roles as centers of community activity. Along with population growth and the economy, the amount of waste in the cities and in tourist areas increases every day. If such conditions are not compensated with serious waste management, the bad effects of waste - such as odor and environmental pollution - are inevitable and will potentially worsen. Unfortunately, the handling of urban waste in Indonesia has not gone well. The construction of the Waste Power Plant (mentioned later as WtE), which is currently seen as the right solution for handling accumulated municipal solid waste is still constrained by various problems.

Moreover, Presidential Regulation number 18 of 2016 concerning the Acceleration of the Construction of Waste-Based Power Plants in DKI Jakarta Province, Tangerang City, Bandung City, Semarang City, Surakarta City, Surabaya City, and Makassar City as a form of Government support for urban waste management has been cancelled by The Supreme Court through Decree number 27 P / HUM / 2016. Management of waste treatment is closely related to sustainable development in each region, and it is implemented by not sacrificing the right of future generations. Thus, sustainable development should be able to manage solid waste and environmental sustainability in the area (Hermawan, 2017). Based on the evidence in other countries, the construction of WtE is one of the main alternatives to reduce waste by at least $70 \%$. The built WtE uses a lot of incineration or thermal technology (by burning waste), which results in an electric energy generator. The support for investors is given by Japan, America, Europe, through tax incentives, subsidies and tipping fees. The tipping fee according to Presidential Decree No. 35 of 2018 concerning the Acceleration of the Construction of Waste Processing Installation into Green Energy-Based Electricity Energy is the cost incurred by the government (regional budget). To waste managers, based on the amount managed per ton, and serves as compensation for waste management services in certain locations beyond the cost of final collection, transportation and processing. Considering the large amount of support provided by the state budget on the development of waste-based renewable energy, further studies need to be conducted on the preparation of a comprehensive incentive scheme to support the issuance of a regulation to replace Perpres 18 of 2016 regarding the acceleration of the construction of waste-based power plants in DKI Jakarta Province, and the cities of Tangerang, Bandung, Semarang, Surakarta, Surabaya and Makassar.

The results of the study and discussion of the replacement of Perpres 18 of 2016 are Perpres 35 of 2018 concerning the Acceleration of the Construction of Waste Processing Installations into Electric Energy Based on Environmentally Friendly Technology. This Perpres expands the previous acceleration area of 7 (seven) cities into 12 (twelve) cities namely (i) DKI Jakarta Province, (ii) Tangerang City, (iii) Bandung City, (iv) Semarang City, (v) Surakarta City, (vi) Surabaya City, (vii) Makassar City, (viii) Bekasi City, (ix) South Tangerang City, (x) Denpasar City, (xi) Palembang City, and (xii) Manado City. The waste handling according to Law Number 23 of 2014 concerning Regional Government is a regional or local affair. However, since it is related to national interests, central government intervention in order to accelerate the development of WtE is necessary. First because the handling of waste is related to reducing emission environmental quality and public health at large Second, WtE is also closely related to the reduction of emissions that can affect economic growth. Third, WtE is also related to electricity services and national energy mix targets (Ministry of Environment and Forestry, 2016). In addition, the realization of WtE also faces various challenges which in some cases cannot be overcome by the regional overnment itself. The Central Government can provide support including creating markets and setting prices. In this regard, in 2015 the Ministry of Energy and 
Mineral Resources issued Minister of Energy and Mineral Resources Regulation Number 44 of 2015 concerning Electricity Purchases by the State Electricity Company (Persero) of the City Waste-Based Power Plant. The regulation requires PT PLN (Persero) to buy electricity from WtE with a flat rate of 20 years. The regulation is then reinforced by Presidential Regulation No. 18 of 2016 concerning the Acceleration of the Construction of Waste-Based Power Plants.

In DKI Jakarta, Tangerang City, Bandung City, Semarang City, Surakarta City, Surabaya City, and Makassar City (Presidential Regulation on WtE Acceleration) unfortunately, the regulation must then face a lawsuit from environmental activists and a group of people. The Presidential Regulation on Acceleration of WtE is deemed not to allow the construction activities and the review on proposed environmental permits to be carried out simultaneously. In addition, the Presidential Regulation on Acceleration of WtE should not emphasize the use of thermal technology which is considered to pose a serious threat to the environment and public health. Other regulations relating to WtE are ESDM Minister Regulation Number 50 of 2017 concerning Utilization of Renewable Energy Sources for Electricity Supply. In addition to requiring PT PLN to buy electricity sourced from renewable energy, the regulation ensures affordable and environmentally friendly electricity prices where electricity purchase prices are: (i) if local electricity generation costs (BBP) are higher than the BPP average national generation, the maximum electricity purchase price is $100 \%$ from the local generation BPP; (ii) if the electricity generation BPP is equal to or lower than the national generation BPP, then the purchase price is carried out in accordance with the agreement (business to business). In addition, based on ESDM Ministerial Decree Number 1404K / 20 / MEM / 2017, the average national BPP in 2016 is USD7.39 cents / $\mathrm{kWh}$. Regions that have BPP below the national average BPP include West Java, Banten, DKI, Central Java, East Java and Bali. While BPP above the national BPP average is Lampung, West Sumatra, North Sumatra, Riau and Riau Islands.

Aceh, Belitung, Bangka, South and West Sulawesi, Kalselteng, Kaltimra, West Kalimantan, North Sulawesi, Papua and West Papua, NTB, Maluku and Maluku the existence of a new Perpres (Presidential Regulation), namely Perpres 35 of 2018 concerning the Accelerated Installation Construction of the Waste Processing into Green Energy-Based Electricity Energy has rearranged the feed in electricity tariff or tariff that applies to 12 WtE acceleration areas, those are USD 13.35 cent per kWh for the capacity $<20$ MW and use formulas for the capacity $>20 \mathrm{MW}$, which is USD 14.54 cent $/ \mathrm{kWh}-(0.076 \mathrm{x}$ WtE capacity $)$. Based on the new tariffs, investors and local governments are expected to be increasingly interested in managing waste into alternative resources or energy, rather than becoming only waste - something that must be disposed of or removed. Management of waste treatment in other countries has been developing for a long time along with the increase in the human population and economic activity. Japan began management of conventional waste in the 1960s, and then has become more advanced by using appropriate technology to overcome the garbage problem. Most of the waste is processed and used as electricity or waste to energy. The technology that is widely used in Japan is Incinerator Technology. Furthermore, Japan has regulated waste management through Law No. 137 of 1970 concerning waste management law which classifies the types of waste and its use. Since from households and industries, waste is sorted by its types based on the selection, some waste will be burned and some other can be used.

Thus, waste management using the reuse, reduce and recylce (3R) system has been planted into the, community up to WtE (Kobayashi, M. et al., 2007). Initially the use of thermal or chemical or thermal incinerator technology was challenged by non-governmental organizations (NGOs) and the community itself because the flying ash releasing dioxins and furans which may cause cancer for humans who inhale them. In addition, the dust (bottom ash) from the results of burning waste can also cause cancer (Ministry of the Environment Japan, 2017). The improvement in incineration technology carried out in Japan has gained high trust from the people that the technology is safe and environmentally friendly. Dissemination to residents regarding the use of incineration technology went smoothly and did not experience obstacles or rejection from the community around the plant, although the WtE was built in the middle of the apartment (Ministry of Environment Japan, 2014). Other than Japan, Indonesia's neighboring country like Singapore has made incinerators as one of the technologies that process waste into energy, namely Waste-Based Power Plants. The use of incinerator technology is seen as more effective and efficient in eliminating or reducing waste significantly. The sorting of 3R waste from households to landfills is well managed by the Singapore Government. In addition, the Singapore Government provides a tipping fee of around 60-70 Singapore Dollars 
to process waste into electricity to investors or managers of WtE (National Environment Agency Singapore, 2018).

\section{Methodology}

In general, the research approach adopted is descriptive qualitative approach using the literature analysis related to several policies and field findings methods. Technical data collection uses survey methods in the sample areas, namely Surabaya, Surakarta and Bandung as cities / regions listed as executors of the accelerated construction of WtE in accordance with Perpres No. 35 of 2018.

\section{Results and Discussion}

Management of Waste Treatment in Surabaya City: The city of Surabaya produces up to 1,600 tons/day from the activities of three million citizens. Based on the data from the Surabaya City Government, the waste generated every day is also contributed by the high level of non-resident activities in the city of Surabaya. Garbage in the city of Surabaya consists of at least 31 types, of which around $60-70 \%$ is wet waste. The Surabaya City Municipal Government has implemented a zero waste policy through the Waste Bank program to carry out 3R activities (reduces reuse, and recycles). This process has succeeded in reducing around 30$40 \%$ of the waste before being sent to the Final Management Site (TPA), so that it is expected to reduce the amount of landfill in TPA. In managing its waste, the City Municipal Government involves the role of private sector through an auction process. Based on memorandum of understanding (MoU), the current corporate selected by the Surabaya City Government to run waste management in TPA Benowo is PT. Sumber Organik, with a system of build, operate, transfer (BOT) since 2011 for a period of 20 years.

Waste management in Surabaya uses a sanitary landfill system, in accordance with the provisions in Law No. 18 of 2008 concerning Waste Management. Benowo landfill area is around 37.4 Ha which is owned by the Surabaya City Government the survey results to TPA Benowo, Surabaya shows that the Surabaya City Government has truly involved the role of the private sector through such actions (Kurniawan, Faizal \& Shintarini, 2014). In this cooperation, the Surabaya City Government invested Rp336 billion in the form of providing 18 hectares of land, while the waste management in Surabaya City Government paid a tipping fee to PT. Sumber Organik of Rp119,000 / ton for the first year. The tipping fee has increased by 7\% per year in the first 10 years. While in the second 10 years there was a 3\% increase per year. For 2016, 2017 and 2018, the tipping fee paid by the Surabaya City Government to PT. Sumber Organik sources are Rp155,985 per ton, Rp166,904 per ton, and Rp.178,587 per ton. The amount of waste generated sent to Benowo Landfill from Surabaya City is 1,600 tons per day (see Table 2).

Table 2: Surabaya City Government Tipping Fee and PT Sumber Organik Contribution

\begin{tabular}{llllllll}
\hline Year & & $\begin{array}{l}\text { Tipping Fee } \\
\text { (Rp/Ton) }\end{array}$ & $\begin{array}{l}\text { Contribution } \\
\text { (Rp Million) }\end{array}$ & Year & & $\begin{array}{l}\text { Tipping Fee } \\
\text { (Rp/Ton) }\end{array}$ & $\begin{array}{l}\text { Contribution } \\
\text { (Rp Million) }\end{array}$ \\
\hline I & 2012 & 119,000 & $3,645.47$ & XI & 2022 & 223,152 & $7,996.04$ \\
II & 2013 & 127,330 & $3,926.16$ & XII & 2023 & 227,165 & $8,682.48$ \\
III & 2014 & 136,243 & $4,233.71$ & XIII & 2024 & 232,168 & $9,431.81$ \\
IV & 2015 & 145,780 & $4,570.48$ & XIV & 2025 & 236,811 & $10,249.65$ \\
V & 2016 & 155,985 & $4,939.05$ & XV & 2026 & 241,547 & $11,142.12$ \\
VI & 2017 & 166,904 & $5,342.24$ & XVI & 2027 & 246,378 & $12,115.92$ \\
VII & 2018 & 178,587 & $5,783.12$ & XVII & 2028 & 251,306 & $13,178.33$ \\
VIII & 2019 & 191,088 & $6,265.02$ & XVIII & 2029 & 256,332 & 14.337 .29 .000 \\
IX & 2020 & 204,464 & $6,791.61$ & XIX & 2030 & 261,458 & 15.601 .460 .000 \\
X & 2021 & 218,777 & $7,367.33$ & XX & 2031 & 266,668 & 16.980 .276 .000 \\
\hline
\end{tabular}

Source: Contract No. 658.I/4347/436.6.5/2012-88/JBU-SO/8/2012, Government of Surabaya with PT Sumber Organik

From the calculations, in 2017 the Surabaya City Municipal Government allocated around Rp. 97.47 billion from the Surabaya City local government to be paid to PT. Sumber Organik. Total Tipping Fee (TF) in 2017 is the multiplication of TF (Rp/ton), volume of waste (tons), and 365 days. The amount of the tipping fee paid 
by the Surabaya City Government is outside the local budget allocated for the process of collecting and transporting waste from the community to the TPA Benowo. In accordance with the MoU between the Surabaya City Government and PT. Sumber Organik, from TPA Benowo, PT Sumber Organik uses methane gas produced from landfill to be used as electricity through biogas technology facilities. Since $2015 \mathrm{WtE}$ Benowo has been able to produce electricity of around $1.5 \mathrm{MW}$ per day, from processing methane gas produced by landfills at Benowo landfill. Furthermore, the electricity produced is sold to PT. PLN with a price of around 18.77 cents USD / kWh which refers to Permen ESDM No. 44 of 2015. The income from the sales of electricity generated from WtE Benowo is entirely the income of PT. Sumber Organik. At present the Surabaya Municipal Government and PT. Sumber Organik is studying the processing of landfill in the Benowo landfill with thermal or combustion technology. It is intended to take advantage of the large amount of existing landfill and also the increasing supply of waste. If the above discourse comes to an implementation agreement, then from Benowo Landfill it is estimated that the electricity of 9 MW output can be produced through.

WtE by utilizing methane gas processing and burning of landfill however, this discourse still needs time considering the cancellation of Presidential Regulation No. 18 of 2016 concerning the Acceleration of WtE Development. At present the substitute regulations are still in the process of discussions between the relevant Ministries. In the old regulation, it accommodated thermal technology in processing waste, and the City of Surabaya was included as one of the seven cities listed in the Presidential Regulation No. 18 of 2016. Regarding cooperation in waste management through the WtE project, the tipping fee paid by the regional government is very much needed as an incentive to invite investment. This is to support the operational costs and maintenance of high WtE technology facilities. An offer from a number of investors who state their readiness to do waste management without the need for tipping fees with electricity rates of 18.77 cents USD / $\mathrm{kWh}$, the credibility and readiness of the such investors needs to be identified further, given the record that cooperation in the construction of WtE involving such investors could not be carried out until now. With the abundant amount of waste supply from the city of Surabaya to Benowo landfill of 1,600 tons / day, 1,000 tons of which will be processed through technical sanitary landfills which can later produce methane gas.

While about 600 tons of the remaining waste will be processed through combustion techniques with the incinerator and continue to utilize the garbage heap that has been around for a long time at Benowo Landfill. In order to maintain the sustainability of WtE Benowo production with combustion technology, a number of cities / regencies around the city of Surabaya are also involved. Related to electricity subsidies allocated in the state budget through PLN bills, the price difference sold by PT Sumber Organik to the East Java Regional PLN PT follows the set price (feed in tariff / FiT) in accordance with Ministerial Regulation ESDM No. 19 of 2013 amounting to Rp1,250 per kWh with a capacity of up to $10 \mathrm{MW}$. The electric power sold by PT Sumber Organik is 1.65 MW since the commercial operation date in December 2015. While the basic cost of supply (BPP) of electricity is Rp1,015.62 per kWh. The electricity subsidies budgeted and provided in the state budget per month are around $\mathrm{Rp} 150$ million to $\mathrm{Rp} 250$ million. The realized electricity subsidies originating from WtE Benowo Surabaya in 2015 amounted to Rp134.83 million, in 2016 amounting to Rp2.89 billion and January - August 2017 amounting to Rp1.96 billion. The sales, purchases, BPP and subsidies from WtE Benowo transactions using sanitary landfill technology can be seen in the following table. 
Table 3: Sales, BPP \& Subsidy WtE Benowo Surabaya with SL Technology

\begin{tabular}{|c|c|c|c|c|c|c|c|}
\hline \multirow[b]{2}{*}{ Month } & \multicolumn{2}{|c|}{ Sent kWh Ammount } & \multirow[b]{2}{*}{$\begin{array}{l}\text { Buy Price } \\
\text { (Rp) }\end{array}$} & \multirow[b]{2}{*}{$\begin{array}{l}\text { Total Price } \\
\text { (Rp Mill.) }\end{array}$} & \multirow[b]{2}{*}{ BPP (Rp) } & \multirow{2}{*}{$\begin{array}{l}\text { Total Cost of } \\
\text { Production } \\
\text { (BPP) (Rp } \\
\text { Mill.) }\end{array}$} & \multirow[b]{2}{*}{$\begin{array}{l}\text { Subsidy } \\
\text { Needs (Rp } \\
\text { Mill.) }\end{array}$} \\
\hline & $\begin{array}{c}\text { up to } 1.65 \mathrm{MW} \\
\text {; Price = } \\
\text { Rp1,250 }\end{array}$ & $\begin{array}{l}>1,65 \mathrm{MW} ; \\
\text { Price = Rp0 }\end{array}$ & & & & & \\
\hline Dec-15 & 720,800 & - & 1,250 & 901.00 & $1,062.93$ & 766.16 & 134.84 \\
\hline Jan-16 & 987,024 & - & 1,250 & $1,233.78$ & $1,015.62$ & $1,002.44$ & 231.34 \\
\hline Feb-16 & 965,520 & - & 1,250 & $1,206.90$ & $1,015.62$ & 980.60 & 226.30 \\
\hline Mar-16 & $1,227,600$ & 15,284 & 1,250 & $1,534.50$ & $1,015.62$ & $1,246.78$ & 287.72 \\
\hline Apr-16 & $1,188,000$ & 2,414 & 1,250 & $1,485.00$ & $1,015.62$ & $1,206.56$ & 278.44 \\
\hline May-16 & $1,087,120$ & - & 1,250 & $1,358.90$ & $1,015.62$ & $1,104.10$ & 254.80 \\
\hline Jun-16 & 914,778 & - & 1,250 & $1,143.47$ & $1,015.62$ & 929.07 & 214.40 \\
\hline Jul-16 & $1,177,000$ & - & 1,250 & $1,471.25$ & $1,015.62$ & $1,195.39$ & 275.86 \\
\hline Aug-16 & 967,660 & - & 1,250 & $1,209.58$ & $1,015.62$ & 982.78 & 226.80 \\
\hline Sep-16 & $1,015,380$ & - & 1,250 & $1,269.23$ & $1,015.62$ & $1,031.24$ & 237.98 \\
\hline Oct-16 & $1,083,480$ & - & 1,250 & $1,354.35$ & $1,015.62$ & $1,100.41$ & 253.94 \\
\hline Nov-16 & $1,061,840$ & - & 1,250 & $1,327.30$ & $1,015.62$ & $1,078.43$ & 248.87 \\
\hline Dec-16 & 672,160 & - & 1,250 & 840.20 & $1,015.62$ & 682.66 & 157.54 \\
\hline Jan-17 & 693,300 & - & 1,250 & 866.63 & $1,025.78$ & 711.17 & 155.45 \\
\hline Feb-17 & 873,520 & - & 1,250 & $1,091.90$ & $1,025.78$ & 896.04 & 195.86 \\
\hline Mar-17 & $1,164,980$ & - & 1,250 & $1,456.23$ & $1,025.78$ & $1,195.01$ & 261.21 \\
\hline Apr-17 & $1,158,720$ & - & 1,250 & $1,448.40$ & $1,025.78$ & $1,188.59$ & 259.81 \\
\hline May-17 & $1,064,520$ & - & 1,250 & $1,330.65$ & $1,025.78$ & $1,091.96$ & 238.69 \\
\hline Jun-17 & $1,101,720$ & - & 1,250 & $1,377.15$ & $1,025.78$ & $1,130.12$ & 247.03 \\
\hline Jul-17 & $1,177,000$ & - & 1,250 & $1,471.25$ & $1,025.78$ & $1,207.34$ & 263.91 \\
\hline Aug-17 & 839,420 & - & 1,250 & $1,049.28$ & $1,025.78$ & 861.06 & 188.22 \\
\hline Total & $21,141,542$ & & & $26,426.93$ & & $21,587.91$ & $4,839.01$ \\
\hline
\end{tabular}

Source: PT PLN, 2017. SL = Sanitary Landfill

The investment costs incurred by PT Sumber Organik on the construction of WtE Benowo with Sanitary Landfill technology with a capacity of $2 \mathrm{MW}$ are around USD 7.05 million or IDR 74.14 billion with an Internal Rate Return (IRR) of 13.70 percent per year and a payback period of 7 years 8 months. The cost of capital in such a case is assumed to be 12 percent per year. The IRR of 13.70 percent is close to the arbitrary number agreed upon and generally above the bank interest. The normal 14\% IRR rate adopted by PLN refers to the coal-fired projects. In addition to the sanitary landfill technology used by PT Sumber Organik, the elimination of waste (zero waste) will also be carried out through a thermochemical technology called gasification. At present, PT Sumber Organik is implementing a WtE construction and the construction is planned to operate in 2018. The electricity tariff sold to PT PLN East Java is estimated using ESDM Regulation No. 44 of 2015, which is USD 18.77 cents per kWh or around IDR 2,533.95 with an exchange rate of IDR 13,500 per USD. The application of high tariff clearly benefits investors and burdens the state budget because the difference between feed in tariff (FiT) and BPP is around Rp1,497.95 per kWh. The need for electricity subsidies from WtE Benowo Thermochemical Gasification in 2018 is estimated at Rp. 94.47 billion. 
Table 4: Sales, BPP \& Subsidy WtE Benowo Surabaya with TG Technology

\begin{tabular}{|c|c|c|c|c|c|c|c|}
\hline Year & $\begin{array}{l}\text { Sent kWh } \\
\text { Amount }\end{array}$ & $\begin{array}{c}\text { Exchange Rate } \\
\text { (Rp/USD) }\end{array}$ & $\begin{array}{l}\text { Unit Price } \\
\text { (Rp/kWh) }\end{array}$ & $\begin{array}{c}\text { Purchasing } \\
\text { Price (Rp } \\
\text { Mill.) }\end{array}$ & BPP (Rp) & $\begin{array}{l}\text { Total Purchase } \\
\text { Price (Rp Mill.) }\end{array}$ & $\begin{array}{c}\text { Subsidy } \\
\text { Needs } \\
\text { (Rp Mill.) }\end{array}$ \\
\hline 2018 & $63,072,000$ & 13500 & $2,533.95$ & 159,821 & 1,036 & $65,344.87$ & 94,476 \\
\hline 2019 & $63,072,000$ & 13500 & $2,533.95$ & 159,821 & 1,046 & $65,998.32$ & 93,823 \\
\hline 2020 & $63,072,000$ & 13500 & $2,533.95$ & 159,821 & 1,057 & $66,658.30$ & 93,163 \\
\hline 2021 & $63,072,000$ & 13500 & $2,533.95$ & 159,821 & 1,067 & $67,324.88$ & 92,496 \\
\hline 2022 & $63,072,000$ & 13500 & $2,533.95$ & 159,821 & 1,078 & $67,998.13$ & 91,823 \\
\hline 2023 & $63,072,000$ & 13500 & $2,533.95$ & 159,821 & 1,089 & $68,678.11$ & 91,143 \\
\hline 2024 & $63,072,000$ & 13500 & $2,533.95$ & 159,821 & 1,100 & $69,364.90$ & 90,456 \\
\hline 2025 & $63,072,000$ & 13500 & $2,533.95$ & 159,821 & 1,111 & $70,058.54$ & 89,763 \\
\hline 2026 & $63,072,000$ & 13500 & $2,533.95$ & 159,821 & 1,122 & $70,759.13$ & 89,062 \\
\hline 2027 & $63,072,000$ & 13500 & $2,533.95$ & 159,821 & 1,133 & $71,466.72$ & 88,355 \\
\hline 2028 & $63,072,000$ & 13500 & $2,533.95$ & 159,821 & 1,144 & $72,181.39$ & 87,640 \\
\hline 2029 & $63,072,000$ & 13500 & $2,533.95$ & 159,821 & 1,156 & $72,903.20$ & 86,918 \\
\hline 2030 & $63,072,000$ & 13500 & $2,533.95$ & 159,821 & 1,167 & $73,632.23$ & 86,189 \\
\hline 2031 & $63,072,000$ & 13500 & $2,533.95$ & 159,821 & 1,179 & $74,368.56$ & 85,453 \\
\hline 2032 & $63,072,000$ & 13500 & $2,533.95$ & 159,821 & 1,191 & $75,112.24$ & 84,709 \\
\hline 2033 & $63,072,000$ & 13500 & $2,533.95$ & 159,821 & 1,203 & $75,863.36$ & 83,958 \\
\hline 2034 & $63,072,000$ & 13500 & $2,533.95$ & 159,821 & 1,215 & $76,622.00$ & 83,199 \\
\hline 2035 & $63,072,000$ & 13500 & $2,533.95$ & 159,821 & 1,227 & $77,388.22$ & 82,433 \\
\hline 2036 & $63,072,000$ & 13500 & $2,533.95$ & 159,821 & 1,239 & $78,162.10$ & 81,659 \\
\hline 2037 & $63,072,000$ & 13500 & $2,533.95$ & 159,821 & 1,252 & $78,943.72$ & 80,878 \\
\hline 2037 & $63,072,000$ & 13500 & $2,533.95$ & 159,821 & 1,264 & $79,733.16$ & 80,088 \\
\hline \multicolumn{2}{|c|}{ TOTAL } & & & $3,356,247$ & & $1,518,562$ & $1,837,685$ \\
\hline
\end{tabular}

Source: PT PLN, 2017. TG = Thermochemical Gasifikasi. BPP = Cost of Production

The investment costs incurred by PT Sumber Organik on the construction of WtE Benowo with Thermochemical Gasification technology with a capacity of 9 MW are around USD 54.18 million or Rp644.43 billion. The figure is calculated with an Internal Rate Return of 13.19 percent per year and a payback period of 8 years 3 months, while the cost of capital is assumed to be 12 percent per year.

Management of Waste Treatment in West Java: Specific waste is rubbish containing hazardous and toxic materials, garbage arising from disasters, building debris, waste that is technically not yet able to be processed and waste that arises periodically. Service compensation, also known as a tipping fee, is the amount of fees that must be paid by the Regional Government, either cities or districts to be used in carrying out the tasks of waste treatment and final processing of waste both technically, socially and environmentally (Cordato, 2001).

Final Waste Processing at Legok Nangka: The management of the Legok Nangka Regional TPPAS is under the control of the Regional Waste Management Center (BPSR), which is a technical implementation unit (UPT) at the West Java Province Environmental Agency. The cost components in the Legok Nangka Regional TPPAS include: (i) Investment costs, which consists of land acquisition, planning, construction of Regional TPPAS facilities, as well as final waste treatment and processing equipment, and (ii) Operational and maintenance costs, which consists of the costs of personnel, fuel, maintenance and maintenance of machinery, materials, building maintenance, overhead and administration. Normally, the operational and maintenance costs of the Legok Nangka regional TPPAS are the responsibility of service providers and are the responsibility of waste-producing regions, including (i) Bandung City, (ii) Cimahi City, (iii) Bandung District, (iv) West Bandung Regency, (v) Sumedang Regency and (vi) Garut Regency, while investment costs are sourced from the West Java Provincial Government. The investment costs for the Legok Nangka Regional TPPAS infrastructure and facilities are amounted to Rp585.29 billion, while the operational and maintenance costs are amounted to Rp67.09 billion per year (see Table 5). The processed waste products will become fuel 
for the cement industry as a substitute for coal for electricity generation. These processed products are usually called briquette refused derived fuel (RDF).

Table 5: Cost of Investment in Infrastructure, Facilities, Operations, Maintenance \& TF at TPPAS Legok Nangka

\begin{tabular}{|c|c|c|c|c|c|}
\hline No & Infrastructure and Facilities & $\begin{array}{l}\text { Cost } \\
\text { (Rp Mill.) }\end{array}$ & No & Components & $\begin{array}{l}\text { Annual Cost } \\
\text { (Rp Mill.) }\end{array}$ \\
\hline 1. & Land provision TPPAS & 35,000 & 1. & Personnel cost & $16,824.30$ \\
\hline 2. & Building Construction & 23.039 & 2. & Fuel & $37,586.16$ \\
\hline 3. & Site Landfill Construction & 113.168 & 3. & OM Machine & $5,125.55$ \\
\hline \multirow[t]{5}{*}{4.} & Work of Waste Management Unit & 381.000 & 4. & Materials & $3,674.55$ \\
\hline & Pre Sorting and Selection & 65.000 & 5. & Building maintenance & $3,501.00$ \\
\hline & Komposting & 65.000 & 6. & Overhead \& Admin. & 385,50 \\
\hline & Recycling & 6.500 & Total & & $67,097.01$ \\
\hline & Briquette refused derived fuel (RDF & 244.500 & & $\begin{array}{l}\text { Garbage } \\
\text { (Tons/year) }\end{array}$ & 547.500 \\
\hline 5. & $\begin{array}{l}\text { Infrastructure and } \quad \text { Facilities } \\
\text { Construction }\end{array}$ & 11.280 & & $\begin{array}{l}\mathrm{TF} \text { Fee } \\
\text { (Rp/Tons) }\end{array}$ & 122.552 \\
\hline 6. & $\begin{array}{l}\text { Procurement of Work Supporting } \\
\text { Facilities }\end{array}$ & 21.762 & & Tipping Fee (Rp/Tons) & 123.000 \\
\hline \multicolumn{2}{|c|}{ Total } & 585.249 & & & \\
\hline
\end{tabular}

Source: Contract Government West of Java, City of Bandung, Cimahi, District Bandung, District. Bandung Barat, District Sumedang and District Garut No. 658.1/62/otdaksm, 658.1/954/PDKBR, 189/36-Perj/2014, 658.1/03-Dispertasih/2014, 612.4/332/DCKTR, 658.1/PKS.17-Huk/2014, \&660.1/991DLHKP, 8 April 2014. TF = Tipping Fee.

In its development, the West Java Provincial Government revised the waste processing in Legok Nangka from RDF to waste combustion using a technology which has been proven and applied in other countries. The garbage from six cities / regencies in West Java has reached 1,820 tons per day. Therefore, the simple technology of SL and the waste processing into RDF are not able to reduce waste to $70 \%$. Based on the joint agreement it was decided that waste management at Legok Nangka was offered to investors on January 29, 2018 through market sounding for PPP bidding process Legok Nangka regional solid waste treatment and final disposal site project. The offer of this project is very attractive to investors because the tipping fee given is a maximum of IDR 386,000 per ton plus the stipulation of electricity rates is estimated at USD 13.44 cents per $\mathrm{kWh}$. It is planned that the construction of WtE begins in 2018.

Final Waste Processing at Regional TPPAS Sarimukti: Sarimukti Regional TPPAS which is located in Cipatat, West Bandung Regency was initially used by the City of Bandung, Cimahi City and West Bandung Regency. However, since 2016, Bandung Regency has been disposing waste without reducing the quota from the previous three regions. The Sarimukti Regional TPPAS comes into operation since Babakan waste disposal facility (TPAS) in Bandung Regency has expired. Bandung Regency does not have other TPAS that can be utilized to overcome the limitations of waste management facility. While Sarimukti Regional TPPAS is a land owned by Perum Perhutani which has been jointly managed with the West Java Provincial Government since 2008 as Sarimukti Compost Processing Site Service compensation (KJP) or tipping fees are also applied to Sarimukti's Temporary Regional TPPAS of IDR 50,000 per ton since the beginning of January 2017. In the previous year, the imposition of KJP was IDR 29,000 per ton. The application of tipping fees can change every year based on the evaluation results from the Regional Government - the institution that so far sends waste to the Sarimukti Temporary Regional TPPAS.

Management of Waste Treatment in Surakarta City: The results of the BKF field survey in Surakarta City show that waste management in Surakarta is a collaboration of local government with investors. Waste final processing sites (TPA) have exceeded capacity, while to find another land is very difficult, thus the local government pioneered cooperation with investors for waste management. The auction phase had been conducted up to 3 times but failed. Later in August 2016 the auction was managed to get a winner, namely PT. 
Citra Metrojaya Putra in a consortium with PT. Energy Housing Development - which is a subsidiary of BUMN Pembangunan Perumahan (PP)- to become PT. Solo Metro Plasma Power Image (SCMPP). In the beginning of 2018 the construction of waste processing should have been completed and begun testing at Putri Cempo landfill. The technical implementing unit that manages regional waste within the West Java Provincial Government is the Regional Waste Management Center under the Environment Agency. The city of Surakarta became the first local government to carry out waste management together with the private sector as investors without tipping fees. There is already an MoU with PLN, once it is managed to produce electricity, the electricity output will be purchased by PLN. The investor main income is from the sale of electricity excluding tipping fees. It is hoped that waste management will continue for up to 20 years. The perceived obstacles to the implementation of this tipping fee are because the first and it is the only one in Indonesia, thus many parties doubt it due to no tipping fees.

The feasibility study is made by investors, and the study is estimated to be completed at the end of 2017 at the time of auction only pre Feasibility Study (FS). It is estimated that investors will get profits with the costs incurred around Rp420 billion. The results of the calculation of the break event point (BEP) or payback period will be reached around 6-6.5 years with a cooperation agreement for 20 years. A power purchase contract agreement is required the expected tariff is in accordance with the Minister of Energy and Mineral Resources Decree Number 44 of 2015. The WtE Putri Cempo is expected to produce a minimum of $4.5 \mathrm{MW}$ of electricity. Since 2016 a Public Private Partnership (PPP) has been established. From the government side, the PPP team members consist of Bappeda, Public Works Agency, and the Legal Bureau. Its task is to bridge the Surakarta City Government and investors, and the team will be upgraded to the UPT level of the waste management UPT. Waste requirements for WtE per day are 450 tons / day, consisting of 250 tons of new waste 200 tons of old waste in the landfill. Since in the future the garbage in Surakarta will not be enough for the needs of WtE Surakarta, Solo Raya needs coordination for the provision of waste from other regions. The adopted technology for waste treatment in Surakarta City is Plasma Gasification. The choice of technology at the time of the third auction was left to investors, and the investors chose plasma gasification. The reason why the technology used is not incinerator, because the latter technology is old and inefficient.

Plasma gasification technology has been carried out in the United States and Nagasaki. The relevant head of the environmental service has once visited Nagasaki and seen the technology is proven operationally effective. The survey results also show that the WtE built does not require tipping fees. This is quite interesting for other LGs that will build WtE using incinerator technology. PT SCMPP benefits only from the sale of electricity (FiT) which is assumed to be USD 18.77 per kWh assuming a 20-year contract. The return on investment is 14.1 percent and the payback period is quite fast at around 6.8 years. Private investment in WtE in Putri Cempo, Surakarta is a favorable choice for the local government and the private sector. Compared to WtE TPA Benowo, Surabaya, it is seen that only PT Sumber Organik which has benefited, while the Surabaya city budget continues to grow with the escalation of tipping fees and the volume of waste generation which continues to increase every year. Based on the survey results, the selection of technology will affect the presence or absence of tipping fees. The choice of technology also affects the volume of waste generated. The choice of technology affects the amount of government support (APBN). The construction of WtE with gasification technology gives a big advantage to investors (IRR and payback period/PBP). Thus, the construction of WtE in Surakarta City only burdens the state budget in the form of electricity subsidies due to the difference between PLN FiT and BPP.

Electricity Subsidies and Challenges in the Management of Waste Treatment: The programs, i.e. Electricity Subsidies and Fiscal Incentives Assistance are intended to support the acceleration of WtE development in accordance with Presidential Decree 58 of 2017 in the areas of DKI Jakarta, Tangerang, Bandung, Semarang, Surakarta, Surabaya, Denpasar and Makassar. Initially the acceleration of WtE development which was included in the national strategic projects was only in three cities, namely Tangerang, Semarang and Makassar. Furthermore, in Presidential Regulation 18 of 2016 which has been revoked by the Supreme Court as many as seven cities, i.e. DKI Jakarta, Tangerang, Bandung, Semarang, Surakarta, Surabaya, and Makassar are also involved. The results of the 2017 survey, there were two additional cities namely Palembang and Manado participating in the acceleration of WtE development. Thus, there would be in total ten cities pr regions accelerating the construction of WtE are given a support by the Central Government. The support is provided by the Government through the APBN includes electricity 
subsidies, tipping fee assistance and generally accepted fiscal incentives. The provision of electricity subsidies is carried out with ESDM Ministerial Regulation Number 44 of 2015, by the determination of electricity tariffs sold by investors to PLN at USD 18.77 per $\mathrm{kWh}$. This large tariff clearly benefits investors and becomes a burden to the Government because there is a difference between the feed in tariff and the cost of supply of PT PLN. The regulation was adjusted by the Ministry of Energy and Mineral Resources in 2017 through numbers 12 and number 50.

Minister Regulation (MR) ESDM No. 12 of 2017 concerning Utilization of Renewable Energy Sources for Electricity Supply in Article 22 states that in the purchase of electricity from WtE for the acceleration of WtE development program, the provisions regarding the purchase and price of electricity are ruled in accordance with the provisions stipulated in legislation before Ministerial Regulation Number 122017 promulgated. Thus, MR ESDM No. 12 of 2017 can not be applied to cities designated as areas for accelerating the construction of WtE infrastructure after Presidential Regulation No. 18 of 2016 was revoked by the Supreme Court at the end of 2016. Thus, the feed in tariff that applies to WtE is USD 18.77 per $\mathrm{kWh}$ as stipulated in ESDM Regulation Number 44 of 2015. Not too long, in early August 2017, the Ministry of Energy and Mineral Resources re-revoked MR ESDM No. 12 of 2017 with ESDM Regulation No. 50 of 2017 concerning Utilization of Renewable Energy Sources for Electricity Supply. Article 26 states that the for purchase of electricity from $\mathrm{WtE}$ for the WtE development acceleration program, the provisions regarding the purchase and price of electricity are ruled in accordance with the provisions stipulated in the legislation before this Ministerial Regulation comes into force. Thus, there is no fundamental change between the Minister of Energy and Mineral Resources No. 50 of 2017 with ESDM Regulation No. 12 of 2017, specifically for the purchase of electricity from WtE. For Surakarta regions or cities that have conducted an auction with PT SCMPP, they will use the BPP Generation in the local electricity system (i.e. Central Java).

Minister of Energy and Mineral Resources Decree No. 1404 K / 20 / MEM / 2017 dated March 27, 2017 states that the amount of BPP Generating PT PLN in 2016 in the Central Java region is USD 6.52 cent per kWh or around Rp868 per kWh. The amount of BPP will almost certainly reduce investors' interest in entering WtE development. Tariff setting in Presidential Regulation No. 18 of 2016 is very high at USD 18.77 cent per kWh or around Rp2499.72 per kWh with an exchange rate of Rp13,307 / USD. Considering the fact that the waste business has become part of the Government affairs, waste management should no longer let the garbage just stacked, but all the waste that enters the landfill should be destroyed. Extermination of waste can be done by direct combustion on incinerator technology or by also processing garbage into refused derived fuel (RDF) which is used as one of the fuels for steam power electricity generation. The technology of incinerator and gasification has become an issue that is constantly being raised by environmental NGOs. The combustion system can produce dust that is harmful to public health. A slightly softer opposition is by gasification because the waste is processed into briquettes. The next challenge is how the development of renewable energy from waste to energy (WtE) can support the target of using renewable energy by 25 percent or 45 GW by 2025 and the government international commitment to reduce greenhouse gases (GHG) by 29 percent or 314 million tons of $\mathrm{CO} 2$ in 2030. Calculation of degradable organic carbon (DOC) states that 0.15 $\mathrm{kg}$ of methane ( $\mathrm{CH} 4)$ is produced by every $1 \mathrm{~kg}$ of dry waste and $\mathrm{CH} 4$ emissions of organic waste is 0.07 $0.11 \mathrm{~kg}$ CH4 per organic waste dry weight (Intergovernmental Panel on Climate Change, 2007).

This commitment has some implications for the state budget, including: (i) the allocation of regional transfers through non-physical DAK increases every year. The provision of tipping fees will lead to injustice for other regions that are not in the area of accelerating WtE development. (ii) State revenues are reduced by providing fiscal incentives, (iii) providing electricity subsidies that are right on target and controlling mandatory spending, and (iv) financing WtE development projects that receive guarantees by the mechanism of government cooperation with business entities (PPP). The PPP mechanism also provides facilities for projects to be implemented such as the viability gap fund (VGF) and availability payment (AP). The VGF and AV provision is supported from the APBN. The Ministry of Energy and Mineral Resources can also issue a special regulation that regulates the purchase price of electricity by PT PLN for WtE, for example, at USD18.77 cents per $\mathrm{kWh}$ as ruled in Permen ESDM No. 44 of 2015. Price regulation is allowed with a more fair and transparent formula by weighing the amount of tipping fees. The greater the tipping fee is imposed, the less the feed in tariff is set by the Government. 
The first proposal for tipping is given to investors in the amount of Rp500,000. Based on the amount of the tipping fee, the selling price of the generator is set at USD 13.35 cents / kWh or equal to Rp.1935.75 at the rate of Rp.14,500. The FiT formula which is proposed for WtE with a capacity of up to 20 MW is USD 13.35 cent per kWh. While capacity $>20 \mathrm{MW}$ is USD 14.54 cent per kWh - $(0.076 \mathrm{x}$ WtE Capacity). The Central Government can provide tipping fee assistance through non-physical Special Allocation Funds (DAK) as long as the Regional Government (District / City) has allocated it in the Regional Budget. Furthermore, the Provincial Government is also obliged to provide tipping fees if the region has not been able to fulfill all tipping fee obligations. The biggest portion of budget for waste management should come from the Regency / City, considering that it is the regional and regional authority that benefits most from the WtE project, which is at least 50 percent of the tipping fee per ton. If funding support for waste management is needed, the Provincial Government should play a bigger role than the Central Government even though the Central Government can also participate at least 25 percent. Tipping fees from non-physical DAK can be given a maximum of 25 percent of the total tipping fee. The provision of tipping fees needs to be regulated in the Minister of Environment and Forestry Regulation. The following table is a simulation of the total tipping fee and electricity subsidies that can be aligned in the 2019 State Budget to the ten cities that are included in the areas selected for accelerating the $\mathrm{WtE}$ development.

Table 6: APBN Support for the Acceleration of WtE Development in Three Cities

\begin{tabular}{|c|c|c|c|c|c|c|c|}
\hline 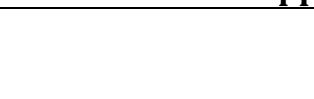 & $\begin{array}{l}\text { Waste } \\
\text { Volume }\end{array}$ & FIT & $\begin{array}{l}\text { Tipping } \\
\text { Fee }\end{array}$ & $\begin{array}{l}\text { Regional } \\
\text { Gov. TF }\end{array}$ & $\begin{array}{l}\text { Prov. Gov. } \\
\text { TF }\end{array}$ & $\begin{array}{l}\text { DAK NF } \\
(A P B N)\end{array}$ & $\begin{array}{l}\text { Electric } \\
\text { Subsidy }\end{array}$ \\
\hline & & & & $(51 \%)$ & $25 \%$ & $24 \%$ & $\begin{array}{l}\text { (State } \\
\text { Budget) }\end{array}$ \\
\hline & (ton) & $(\mathrm{Rp} / \mathrm{kWh})$ & (Rp/ton) & (Bill. Rp) & (Bill. Rp) & (Bill. Rp) & (Bill. Rp) \\
\hline Surabaya (9 MW) & 1.000 & $1.935,75$ & 500.000 & 93,07 & 45,62 & 43,80 & 56,74 \\
\hline $\begin{array}{l}\text { Jawa Barat (20 } \\
\text { MW) }\end{array}$ & 1.820 & $1.935,75$ & 500.000 & 169,39 & 83,03 & 79,71 & 284,59 \\
\hline $\begin{array}{l}\text { Surakarta (5 MW) } \\
\text { Total }\end{array}$ & 450 & $1.935,75$ & 500.000 & 41,88 & 20,53 & $\begin{array}{l}19,71 \\
143.22\end{array}$ & $\begin{array}{l}42,33 \\
383,66\end{array}$ \\
\hline
\end{tabular}

Source: Simulation Output, 2018

The State Budget support related to waste management in 2019 is as follows: (i) Electricity subsidies for three cities are Rp383.66 Billion (ii) Non-Physical DAK assistance with a maximum criteria of $25 \%$ is Rp143.22 Billion. The total Support for the 2019 State Budget is Rp526.88 billion.

\section{Conclusion}

The main objective of WtE development is to destroy waste, while electricity is an additional benefit. Moreover, the efficiency of WtE to produce electricity has so far only reached 17 percent. According to Law No. 32 of 2014 concerning Regional Government, waste management is a regional affair so that the provision of tipping fees becomes an obligation of the region. The waste treatment using the thermal technology is the most suitable for the city Surabaya, Surakarta and West Java Province (those accelerating the construction of WtE), because it is most effective in reducing landfill. In the waste treatment, a number of regions have adopted a tipping fee policy, which is a waste processing fee outside of the collection, transportation and delivery of garbage. The amount of tipping fee provided in the local budget three cities around Rp150,000$\mathrm{Rp} 400,000$ tons of garbage. The imposition of tipping fees is a natural thing as also applied in several other countries such as Japan, America, Sweden, Denmark and Finland. The support provided by the central government to local governments that have managed their waste includes (i) electricity subsidies through the difference in tariffs set by the government with the cost of supply from plants around USD 6-7 cents per kWh, and (ii) assistance with tipping fees from state budget is a maximum of $49 \%$ of the total cost of waste management services.

Recommendations: The amount of tipping fee for each region should be adjusted to the characteristics of the waste, the area, and the location of the landfill. The purchase price of electricity from WtE for a certain rupiah needs to be stipulated in the revised Perpres No. 18 of 2016 to provide certainty reasonable prices to investors. The things that need to be addressed in the provision of tipping fees are the supportive regulatory 
framework for providing assistance to other regions. Currently, the assistance provision always needs legislative annual approval. In addition, to provide certainty to investors, the Regional Government needs to issue a statement that waste to energy investment is supported during the contract.

Thus, the change of regional head and local senators does not affect the contracts that have been carried out by the previous government. Considering the large amount of support provided by the state budget on the development of waste-based EBT, further studies need to be conducted on the preparation of a comprehensive incentive scheme to support the issuance of a Perpres 18 of 2016 regarding the acceleration of the construction of waste-based power plants in DKI Jakarta Province, Tangerang City, Bandung City, Semarang City, Surakarta City, Surabaya City and Makassar City. The plan for issuing a new Perpres also needs to accommodate other cities such as Denpasar City other cities in Bali, Palembang City and Manado City. These cities are possible to obtain additional regional incentive funds that have managed their waste well. Further studies on the development of garbage or waste-based WtE also need to calculate the fiscal burden in the state budget. This burden arises if more and more regions need the support of the Central Government through electricity subsidies, tipping fee assistance through non-physical DAK and tax incentives. Another thing that is quite important from the follow-up study is the calculation of the value of emissions from waste which was previously only disposed of to landfill compared to being destroyed and utilized as electricity.

\section{References}

Hermawan, F. (2017). Penerapan Teknologi Waste to Energy (WTE) Pada Rencana Pembangunan Intermediate Treatment Facility (ITF) Sunter Jakarta Utara, Dinas Lingkungan Hidup Provinsi DKI Jakarta, April 2017.

Intergovernmental Panel on Climate Change. (2007). Climate Change 2007: Synthesis Report. Contribution of Working Groups I, II and III to the Fourth Assessment Report of the Intergovernmental Panel on Climate Change [Core Writing Team, Pachauri, R.K and Reisinger, A. (eds.)]. IPCC, Geneva, Switzerland, 104.

Kementerian Energi dan Sumber Daya Mineral. (2015). Kebijakan Pengembangan Sampah Menjadi Energi di Indonesia. Buku Panduan, Direktorat Jenderal Energi Baru Terbarukan dan Konservasi Energi, Desember 2015.

Kementerian Lingkungan Hidup dan Kehutanan. (2016). Pemanfaatan Sampah Rumah Tangga dan Sampah Sejenis Sampah Rumah Tangga Sebagai Bahan Bakar Alternatif Refuse-Derived Fuel (RDF).

Kobayashi, M. et al. (2007). Physiological analysis of yeast cells by flow cytometry during serial-repitching of low-malt beer fermentation. Journal of Bioscience and Bioengineering, 103(5), 451-456.

Kurniawan, F. \& Shintarini, S. (2014). Klausula Tipping Fee Dalam Kontrak Kerjasama Pemerintah Dengan Swasta (Public-Private Partnership) Pengelolaan Persampahan. Jurnal Hukum Vol. IV No. 1, 2014, Fakultas Hukum Universitas Airlangga.

Ministry of the Environment, Japan. (2014). History and Current State of Waste Management in Japan, Waste Management and Recycling Department, February 2014, compiled by: Japan Environmental Sanitation Center.

Ministry of the Environment, Japan. (2017). Feasibility Study of Joint Crediting Mechanism Project by City to City Collaboration Waste to Energy Power Plant Project for Bali Province in Indonesia Final Report, 10th March, 2017 JFE Engineering Corporation Clean Authority of TOKYO.

National Environment Agency Singapore. (2018). Waste-to-Energy Incineration Plants. Waste Management Infrastructure. Singapore Government.

United Nations Environment Programme. (2015). International Solid Waste Association. Global Waste Management Outlook: Summary For Decision-Makers. United Nations Environment Programme. 